\title{
A novel PDGFRA mutation in gastrointestinal stromal tumours, L839P, is sensitive to imatinib in vitro
}

\author{
CHENGUANG BAI $^{1 *}$, XIAOHONG LIU ${ }^{2 *}$, JIAN-MING ZHENG $^{1,3^{*}}, \mathrm{CEN}$ QIU $^{1}$, \\ YAN ZHU ${ }^{3}$, JINGJING XU ${ }^{1}$, JING ZHAO ${ }^{3}$ and DALIE MA ${ }^{1}$ \\ ${ }^{1}$ Department of Pathology; ${ }^{2}$ Institute of Cardiothoracic Surgery; \\ ${ }^{3}$ Institute of Molecular Pathology, Changhai Hospital, Shanghai, P.R. China
}

Received November 25, 2011; Accepted January 23, 2012

DOI: $10.3892 / \mathrm{ol} .2012 .599$

\begin{abstract}
Evidence suggests that different types of mutation in gastrointestinal stromaltumours(GISTs)correlate with different response rates to imatinib (Glivec, STI571). The purpose of this study was to explore the sensitivity of the PDGFRA ${ }^{\text {L839P }}$ mutant, a novel gain-of-function mutation isoform related to GISTs, to imatinib in vitro. The eukaryotic expression vectors pcDNA3.1-PDGFRA ${ }^{\text {Wild }}$, pcDNA3.1-PDGFRA ${ }^{\text {D842V }}$ and pcDNA3.1-PDGFRA ${ }^{\text {L839P }}$ were constructed and transfected into Chinese hamster ovary $(\mathrm{CHO})$ cells by liposome methods. The responses of cells with PDGFRA ${ }^{\text {Wild }}$, PDGFRA ${ }^{\mathrm{L} 839 \mathrm{P}}$ and $P D G F R A^{\mathrm{D} 842 \mathrm{~V}}$ mutants to imatinib were determined by methyl thiazolyl tetrazolium (MTT) assay, western blotting and apoptosis assays. Reults of the MTT assay revealed that the growth rate of $\mathrm{CHO}\left(\mathrm{PDGFRA}^{\mathrm{L} 839 \mathrm{P}}\right)$ cells decreased to approximately $60 \%$ when exposed to $1 \mu \mathrm{M}$ imatinib and to approximately $50 \%$ with $5 \mu \mathrm{M}$ imatinib. However, the growth rate of $\mathrm{CHO}\left(\mathrm{PDGFRA}^{\mathrm{D} 842 \mathrm{~V}}\right)$ cells did not significantly change with $5 \mu \mathrm{M}$ imatinib. Western blot analysis indicated that $1 \mu \mathrm{M}$ imatinib completely blocked the phosphorylation of PDGFRA $^{\text {L839P }}$, but did not affect PDGFRA ${ }^{\text {D842V }}$ phosphorylation. Apoptosis analysis suggested that the percentage of apoptotic $\mathrm{CHO}\left(\mathrm{PDGFRA}^{\mathrm{L} 839 \mathrm{P}}\right)$ cells increased approximately 4-fold (from 5.90 to $25.2 \%$ ) with $1 \mu \mathrm{M}$ imatinib. Although the treatment of $\mathrm{CHO}\left(\mathrm{PDGFRA}^{\mathrm{D} 842 \mathrm{~V}}\right)$ and $\mathrm{CHO}\left(\mathrm{PDGFRA}^{\text {Wild }}\right)$
\end{abstract}

Correspondence to: Dr Dalie Ma, Department of Pathology, Changhai Hospital, 168 Changhai Road, Shanghai 200433, P.R. China

E-mail: mdlie@163.com

*Contributed equally

Abbreviations: ATP, adenosine triphosphate; FITC, fluorescein isothiocyanate; GAPDH, glyceraldehyde-3-phosphate dehydrogenase; GIST, gastrointestinal stromal tumour; MTT, methyl thiazolyl tetrazolium; PBS, phosphate-buffered solution; PDGFR, plateletderived growth factor receptor

Key words: PDGFRA mutant, imatinib, drug sensitivity, gastrointestinal stromal tumour cells with $5 \mu \mathrm{M}$ imatinib resulted in a slight increase in the number of apoptotic cells, the percentage of apoptotic cells remained approximately $10 \%$ of the total population. Our findings showed that the PDGFRA gene mutation isoform L839P is sensitive to inhibition by imatinib. Screening for PDGFRA mutations in GISTs is essential to identify the response to treatment with imatinib.

\section{Introduction}

Gastrointestinal stromal tumours (GISTs) are the most common mesenchymal neoplasms of the gastrointestinal tract and are believed to originate from the interstitial cells of Cajal (1-3). GISTs are characterised by the expression of the type III receptor tyrosine kinase KIT encoded by the KIT protooncogene (4), thus KIT immunohistochemistry has been used as a diagnostic marker of GISTs $(4,5)$. Since Hirota et al (6) first reported the KIT mutation in 1998, a number of studies have reported that the majority of GISTs have oncogenic mutations in $\operatorname{KIT}(7,8)$. A small subset of GISTs was also found to possess activating mutations in the platelet-derived growth factor receptor A (PDGFRA) gene $(9,10)$.

Therapeutic targeting with the tyrosine kinase inhibitor imatinib (Glivec, STI571) has been shown to be effective in patients with advanced or unresectable GISTs $(11,12)$. Imatinib is an inhibitor of a number of tyrosine kinases, including the intracellular kinase ABL, the growth factor receptors KIT and PDGFR-A and -B and their oncogenic activated forms (13). Imatinib competes with adenosine triphosphate (ATP) for the ATP-binding site of the kinases, preventing downstream signalling $(14,15)$. Imatinib is now successfully used in the treatment of advanced GISTs $(16,17)$ and chronic myelogenous leukaemia $(18,19)$. Its clinical activity in other neoplasms has also been reported, including chordoma (20) and dermatofibrosarcoma protuberans (21).

Evidence suggests that different types of mutation in GISTs correlate with different response rates to imatinib (22). Previous studies have demonstrated that the majority of GISTs with a KIT mutation were sensitive to imatinib, but GISTs with a $P D G F R A$ mutation were mostly resistant to imatinib. Most of the PDGFRA mutations found in GISTs have been identified in exon 18 and are the imatinib-resistant substitution D842V. Only approximately one-third of PDGFRA mutations 
in GISTs have been found in exons 12 and 14 and these mutations have different responses to imatinib (23). We previously studied the PDGFRA mutation types of exon 12 and 18 by PCR amplification and DNA sequencing in a series of Chinese GISTs. Compared with the reports in the published data, a point mutation at codon $839, \mathrm{~L} 839 \mathrm{P}$, lies outside the hot spot area (23). Further studies confirmed that $P D G F R A^{\mathrm{L} 839 \mathrm{P}}$ is a gain-of-function mutation (24). To explore the response of $P D G F R A^{\mathrm{L} 839 \mathrm{P}}$ to imatinib, we transfected different isoforms of the human PDGFRA gene into Chinese hamster ovary (CHO) cells and compared the inhibitory effects of imatinib on PDGFRA ${ }^{\mathrm{L} 839 \mathrm{P}}$ with the effects on PDGFRA ${ }^{\mathrm{D} 842 \mathrm{~V}}$ in vitro concerning cell growth, apoptosis and receptor phosphorylation level.

\section{Materials and methods}

PDGFRA expression constructs. The wild-type human PDGFRA cDNA (HD Biosciences Co, Shanghai, China) was cloned into the pcDNA3.1hygro+ vector to create pcDNA3.1PDGFRA $^{\text {Wild }}$. cDNA encoding the human PDGFRA mutant isoforms was generated using a MutanBEST site-specific mutagenesis kit (Takara Bio, Inc., Shiga, Japan) using the primers: 5'-CTGTGACTTTGGCCCGGCCAGAGACATCATG-3' and 5'-CATGATGTCTCTGGCCGGGCCAAAGTCACAG-3' for the PDGFRA ${ }^{\mathrm{L} 839 \mathrm{P}} \mathrm{cDNA}$, and 5'-GGCCTGGCCAGAGT CATCATGCATGATTCG-3' and 5'-CGAATCATGCATGAT GACTCTGGCCAGGCC-3' for the PDGFRA ${ }^{\text {D842V }}$ cDNA. A $\sim 3.3-\mathrm{kb}$ product was obtained by denaturation for $1 \mathrm{~min}$ at $94^{\circ} \mathrm{C}$, annealing for $1 \mathrm{~min}$ at $56^{\circ} \mathrm{C}$ and extension for $1 \mathrm{~min}$ at $72^{\circ} \mathrm{C}$ for 30 cycles. These fragments were digested with XhoI and NheI and directionally cloned into the pcDNA3.1hygro+ vector. All vectors were confirmed by restriction endonuclease digestion and bidirectional sequencing.

Transfection of $\mathrm{CHO}$ cell lines. To transfect $\mathrm{CHO}$ cells with plasmids encoding human $P D G F R A^{\text {Wild }}, P D G F R A^{\mathrm{D} 842 \mathrm{~V}}$ and PDGFRA ${ }^{\mathrm{L} 839 \mathrm{P}}$, Lipofectamine ${ }^{\mathrm{TM}} 2000$ (Invitrogen, Carlsbad, CA, USA) was used according to the manufacturer's instructions. Infectants were selected with $1 \mathrm{mg} / \mathrm{ml}$ Hygromycin B (Merck, Darmstadt, Germany) until all the uninfected control cells were killed. Following selection, the $\mathrm{CHO}$ cells were cultured in medium containing $0.5 \mathrm{mg} / \mathrm{ml}$ Hygromycin B.

Flow cytometric analysis of apoptosis. The CHO cell lines were cultured in the presence or absence of imatinib for $24 \mathrm{~h}$. Subsequently, apoptosis was detected using an annexin V-fluorescein isothiocyanate (FITC) staining kit (Roche, Mannheim, Germany). The cells were harvested by trypsinisation and labelled with annexin V-FITC for $15 \mathrm{~min}$ at $4^{\circ} \mathrm{C}$ and analysed by FACSCalibur flow cytometry.

Methyl thiazolyl tetrazolium (MTT) assay. Cells were added to 96 -well plates at a density of $2 \times 10^{4}$ cells/well. After the cells were maintained for $24 \mathrm{~h}$ at $37^{\circ} \mathrm{C}$ in a $5 \% \mathrm{CO}_{2}$ atmosphere, a $200 \mu \mathrm{l}$ solution containing imatinib $(0,0.001,0.01$, $0.1,1$ or $5 \mu \mathrm{M})$ was added. After $72 \mathrm{~h}, 20 \mu \mathrm{l}$ of a $5 \mathrm{mg} / \mathrm{ml}$ solution in PBS of the MTT (Sigma, St. Louis, MO, USA) tetrazolium substrate was added and the cells were incubated for $4 \mathrm{~h}$ at $37^{\circ} \mathrm{C}$. The resulting violet formazan precipitate was

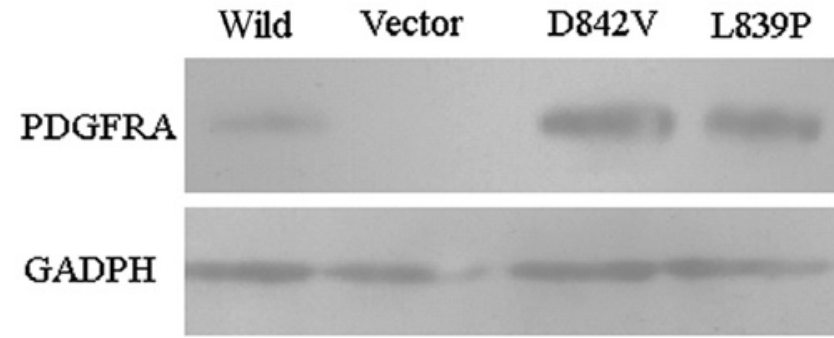

Figure 1. Expression of human PDGFRA protein in each group of $\mathrm{CHO}$ cells. The results of the western blot analysis showed that human PDGFRA protein was expressed in $\mathrm{CHO}$ (Wild), $\mathrm{CHO}(\mathrm{D} 842 \mathrm{~V})$ and $\mathrm{CHO}(\mathrm{L} 839 \mathrm{P})$ cells, but not $\mathrm{CHO}$ (vector) cells. The level of expression of human PDGFRA in $\mathrm{CHO}(\mathrm{D} 842 \mathrm{~V})$ and $\mathrm{CHO}(\mathrm{L} 839 \mathrm{P})$ cells was higher than that in $\mathrm{CHO}$ (Wild) cells. $\mathrm{CHO}$, Chinese hamster ovary.

solubilised by the addition of $150 \mu \mathrm{l}$ DMSO (Amresco, Solon, $\mathrm{OH}, \mathrm{USA}$ ) and incubated for $10 \mathrm{~min}$ at room temperature. Sample absorbances were then measured on a plate reader at $540 \mathrm{~nm}$.

Western blotting. Whole-cell lysates were prepared by resuspending the cells in cold SDS buffer [1\% SDS, $0.04 \mathrm{~mol} / \mathrm{l}$ Tris- $\mathrm{HCl}$ (pH 6.8), 5\% glycerol]. The protein concentrations were determined using a commercial BCA protein assay kit (Merck). Protein extracts were added at a 4:1 ratio to 5X SDS sample buffer and boiled. The protein $(50 \mu \mathrm{g})$ was resolved on a $10 \%$ polyacrylamide gel and transferred to polyvinylidene difluoride membranes (Millipore, Billerica, MA, USA). The membranes were probed with anti-PDGFRA rabbit polyclonal antibody (Santa Cruz Biotechnology, Inc., Santa Cruz, CA, USA), anti-GAPDH goat polyclonal antibody (GenScript, Piscataway, NJ, USA) or anti-phosphotyrosine monoclonal antibody (Long Island Biotech Inc., New York, USA). The signals were detected using the western blotting luminal reagent (Santa Cruz Biotechnology, Inc.).

\section{Results}

Identification of recombinant plasmids. Following digestion by XhoI and NheI, bands at $3.3 \mathrm{kDa}$ were detected for the positive clones, suggesting that $P D G F R A^{\text {wild, }}$ $P D G F R A^{\mathrm{L} 839 \mathrm{P}}$ and $P D G F R A^{\mathrm{D} 842 \mathrm{~V}}$ fragments were inserted into the pcDNA3.1 vector, designated as recombinant plasmids pcDNA3.1-PDGFRA ${ }^{\text {Wild }}$, pcDNA3.1-PDGFRA ${ }^{\text {L839P }}$ and pcDNA3.1-PDGFRA $^{\text {D842V }}$, respectively.

pcDNA3.1-PDGFRA ${ }^{\text {Wild }}$, pcDNA3.1-PDGFRA ${ }^{\text {L839P }}$ and pcDNA3.1-PDGFRA ${ }^{\text {D842V }}$ DNA was prepared for sequencing. The sequence obtained was the same as the reported sequence of PDGFRA cDNA and mutant PDGFRA cDNA, indicating that the wild-type and mutant PDGFRA genes were successfully cloned into the eukaryotic expression vector pcDNA3.1.

Liposome transfer of PDGFRA Wild, PDGFRA ${ }^{D 842 V}$ and PDGFRA ${ }^{L 839 P}$ into CHO cell lines. CHO cells were transfected with Lipofectamine ${ }^{\mathrm{TM}} 2000$ encoding human PDGFRA $A^{\text {Wild }}, P D G F R A^{\mathrm{D} 842 \mathrm{~V}}$ and PDGFR ${ }^{\mathrm{L} 839 \mathrm{P}}$. Following selection in medium containing $1 \mathrm{mg} / \mathrm{ml}$ Hygromycin $\mathrm{B}$, the $\mathrm{CHO}$ cells were raised in medium containing $0.5 \mathrm{mg} /$ $\mathrm{ml}$ Hygromycin B. The expression of human PDGFRA was 

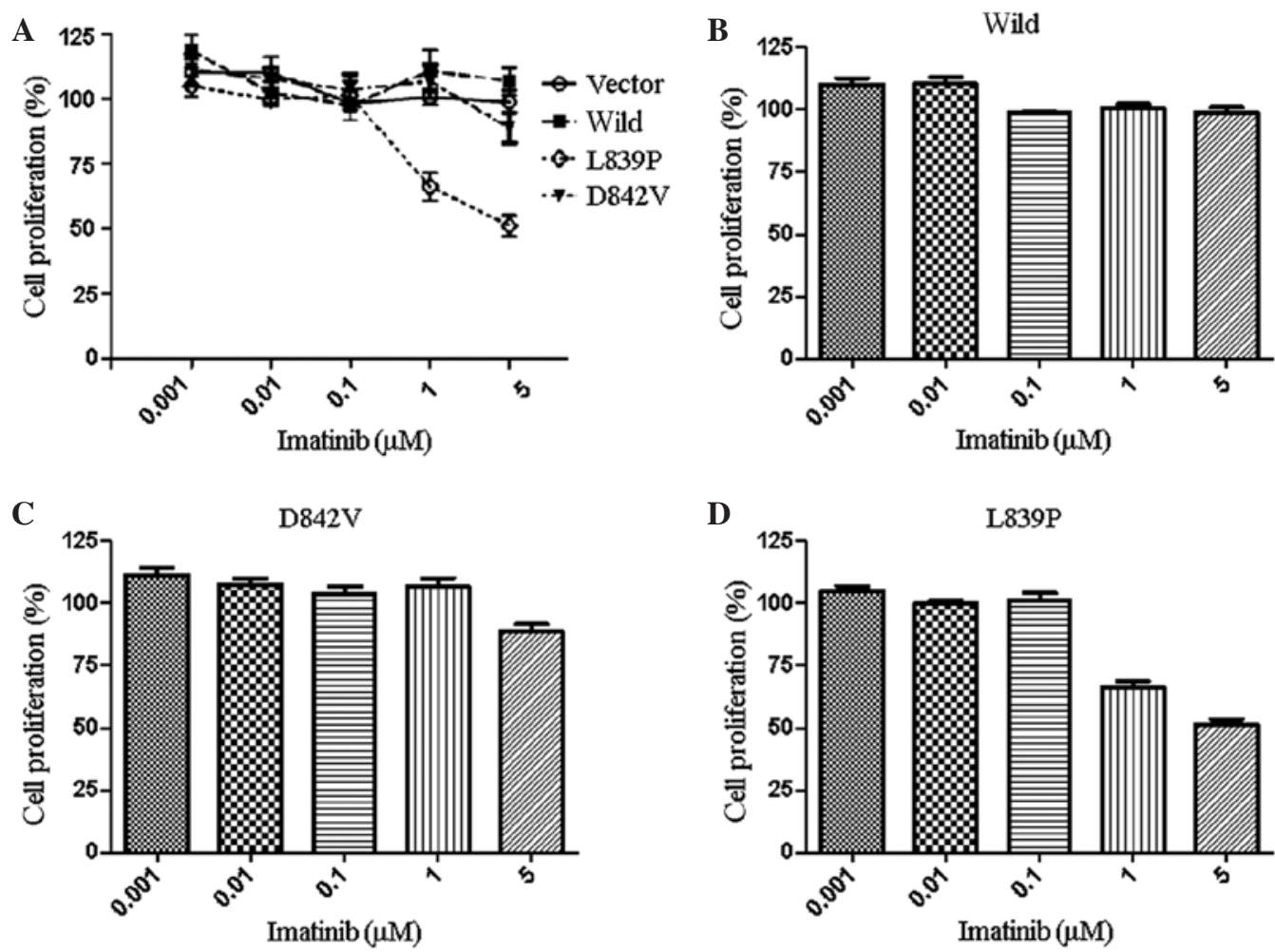

Figure 2. Effect of imatinib on the growth of each group of $\mathrm{CHO}$ cells. The results of the MTT cell proliferation analysis indicated that the proliferation of $\mathrm{CHO}(\mathrm{L} 839 \mathrm{P})$ cells was inhibited by imatinib at a concentration of $1 \mu \mathrm{M}$ (A and D). By contrast, the proliferation of the other cell lines, including $\mathrm{CHO}(\mathrm{D} 842 \mathrm{~V})$, was not greatly affected by imatinib at concentrations of $\geq 5 \mu \mathrm{M}$ (A-C). $\mathrm{CHO}$, Chinese hamster ovary.

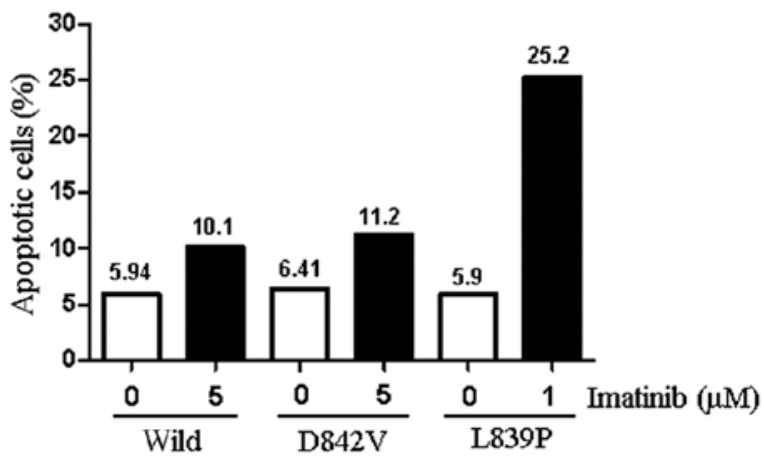

Figure 3. Imatinib induces apoptosis in each group of $\mathrm{CHO}$ cells. Apoptotic cells were detected by staining with Annexin-V and analysis by flow cytometry, following the culture of $\mathrm{CHO}$ cells in the presence of imatinib for $24 \mathrm{~h}$. $\mathrm{CHO}$ (L839P) cells in $1 \mu \mathrm{M}$ imatinib had an $\sim 4$-fold increase in the percentage of apoptotic cells. Although the incubation of $\mathrm{CHO}(\mathrm{D} 842 \mathrm{~V})$ and $\mathrm{CHO}$ (Wild) cells in $5 \mu \mathrm{M}$ imatinib resulted in a slight increase in the number of apoptotic cells, the percentage of apoptotic cells remained $\sim 10 \%$ of the total population. Similar results were obtained when the experiment was repeated. $\mathrm{CHO}$, Chinese hamster ovary.

examined using western blot analysis (Fig. 1). Results indicated that human PDGFRA was expressed in $\mathrm{CHO}$ (Wild), $\mathrm{CHO}(\mathrm{D} 842 \mathrm{~V})$ and $\mathrm{CHO}(\mathrm{L} 839 \mathrm{P})$ cells, but not $\mathrm{CHO}$ (vector) cells. The level of expression of human PDGFRA protein in the $\mathrm{CHO}(\mathrm{D} 842 \mathrm{~V})$ and $\mathrm{CHO}(\mathrm{L} 839 \mathrm{P})$ cells was higher than that in the $\mathrm{CHO}$ (Wild) cells.

Mutation isoforms of the PDGFRA gene affect the sensitivity to imatinib. The effect of imatinib on the growth of $\mathrm{CHO}$ (vector),
$\mathrm{CHO}$ (Wild), $\mathrm{CHO}(\mathrm{D} 842 \mathrm{~V})$ and $\mathrm{CHO}(\mathrm{L} 839 \mathrm{P})$ cells was evaluated using an MTT assay that measures the number of live cells at the end of a 72-h culture period. The proliferation of $\mathrm{CHO}$ (L839P) cells was inhibited by imatinib at concentrations of $1 \mu \mathrm{M}$ (Fig. 2A and D). By contrast, the remaining cell lines, including $\mathrm{CHO}(\mathrm{D} 842 \mathrm{~V})$, were not greatly affected by the presence of imatinib at concentrations of $\geq 5 \mu \mathrm{M}$ (Fig. 2A-C). These results suggest that the $\mathrm{CHO}(\mathrm{L} 839 \mathrm{P})$ cell line is more sensitive to inhibition by imatinib than $\mathrm{CHO}(\mathrm{D} 842 \mathrm{~V})$ and $\mathrm{CHO}$ (Wild) cells, indicating that the L839P mutation of the PDGFRA gene may be sensitive to imatinib, but the $\mathrm{D} 842 \mathrm{~V}$ mutation is resistant to imatinib.

Imatinib induces apoptosis in $\mathrm{CHO}$ cells. To determine whether growth inhibition was caused by the induction of apoptosis, staining with Annexin-V and propidium iodide was used. Following the incubation of $\mathrm{CHO}$ (vector) cells in $5 \mu \mathrm{M}$ imatinib, the percentage of apoptotic cells remained $\sim 10 \%$ of the total population. By contrast, incubation of $\mathrm{CHO}(\mathrm{L} 839 \mathrm{P})$ in $1 \mu \mathrm{M}$ imatinib resulted in a $\sim$-fold increase in the percentage of apoptotic cells. Although the incubation of $\mathrm{CHO}(\mathrm{D} 842 \mathrm{~V}$ ) and $\mathrm{CHO}$ (Wild) cells in $5 \mu \mathrm{M}$ imatinib resulted in a slight increase in the number of apoptotic cells, the percentage of apoptotic cells remained $\sim 10 \%$ of the total population (Fig. 3). Similar results were obtained when the experiment was repeated.

Effect of imatinib on receptor phosphorylation. To determine the effect of imatinib on the autophosphorylation of PDGFRA, a western blot for PDGFRA and phosphotyrosine was 


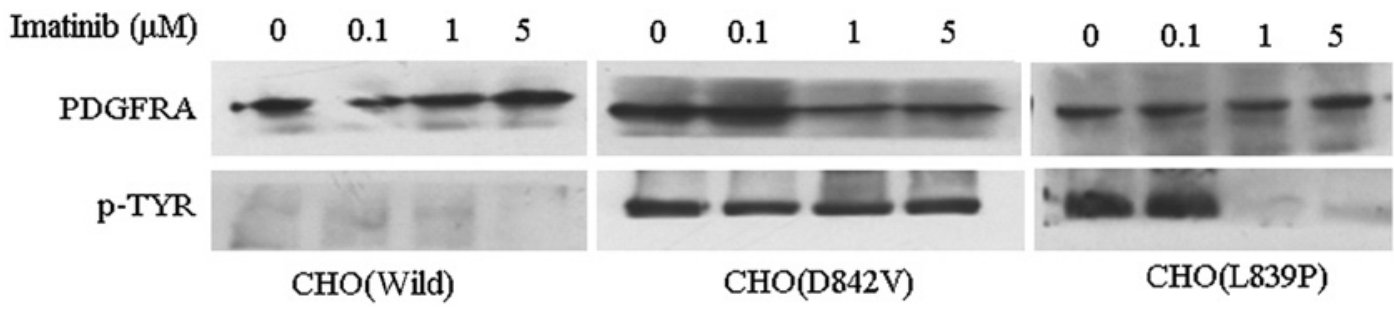

Figure 4. Effect of imatinib on the phosphorylation level of the PDGFRA protein in each group of CHO cells. The figure shows the results of the western blot analysis of the PDGFRA protein and its phosphorylated forms following the incubation of each group of CHO cells with imatinib for 90 min. The level of PDGFRA phosphorylation in $\mathrm{CHO}$ (Wild) cells was low. By contrast, the level of receptor phosphorylation in $\mathrm{CHO}(\mathrm{D} 842 \mathrm{~V})$ cells was unaffected by $5 \mu \mathrm{M}$ imatinib. There was no phosphorylation of PDGFRA in CHO(L839P) cells treated with 1 and $5 \mu$ M imatinib. p-TYR, phosphotyrosine; CHO, Chinese hamster ovary.

performed (Fig. 4). The phosphotyrosine levels revealed that PDGFRA phosphorylation in $\mathrm{CHO}$ (Wild) cells was low. By contrast, the receptor phosphorylation in $\mathrm{CHO}(\mathrm{D} 842 \mathrm{~V})$ was unaffected by $5 \mu \mathrm{M}$ imatinib. There was no phosphorylation of PDGFRA in CHO(L839P) cells treated with 1 and $5 \mu \mathrm{M}$ imatinib. These results correlate well with those of the MTT assays, indicating that $\mathrm{CHO}(\mathrm{L} 839 \mathrm{P})$ cells are sensitive to $1 \mu \mathrm{M}$ imatinib, whereas $\mathrm{CHO}(\mathrm{D} 842 \mathrm{~V})$ cells are resistant to imatinib.

\section{Discussion}

GISTs are the most common mesenchymal neoplasms of the gastrointestinal tract (1-3). Despite clinicopathological differences, most GISTs share a similar genetic profile, including KIT or PDGFRA gene gain-of-function mutations $(25,26)$, which are targets for the kinase inhibitor imatinib $(13,27)$. Previous clinical studies have shown that imatinib is effective in patients with advanced or unresectable GISTs $(11,12)$. Further studies have demonstrated that different responses of GIST patients to imatinib correlate with different mutation types $(22,28)$. Results of the study by Corless $e t$ al suggest that approximately $62.6 \%$ of PDGFRA-mutant tumours are resistant to imatinib (23). In other words, only just over a third of GISTs with PDGFRA mutations may respond to imatinib. Therefore, mutation screening may aid in the management of GIST patients.

In our previous studies, a novel point mutation in exon 18 of the PDGFRA gene (L839P) was found in two GIST cases (24) and lies outside of the hot spot. To compare the inhibitory effects of imatinib on PDGFR $A^{\mathrm{L} 839 \mathrm{P}}$ with the effects on PDGFRA $A^{\mathrm{D} 842 \mathrm{~V}}$ in vitro with the mutations expressed individually in the same cellular background, we used liposome transduction to transfect these forms of PDGFRA into $\mathrm{CHO}$ cells. The D842V mutation is the most common mutation of the PDGFRA gene in GISTs. Preliminary data suggested that $\mathrm{D} 842 \mathrm{~V}$ is resistant to imatinib in vitro and in vivo (22). In the present study, the MTT assay results indicated that the PDGFRA mutant isoform D842V shows significant resistance to imatinib at $1 \mu \mathrm{M}$, which is equivalent to the highest serum levels generally achieved in patients, according to other studies (29). Compared with D842V, the L839P mutation of the PDGFRA gene was sensitive to $1 \mu \mathrm{M}$ imatinib in vitro, suggesting that GISTs carrying the PDGFRA ${ }^{\mathrm{L} 839 \mathrm{P}}$ mutation may have a better response to imatinib. To determine whether growth inhibition was caused by the induction of apoptosis, staining with Annexin-V was used. The results suggest that imatinib notably induces cell apoptosis in $\mathrm{CHO}(\mathrm{L} 839 \mathrm{P})$ cells and enhances the response to imatinib.

To determine the effect of imatinib on autophosphorylation of PDGFRA, western blots for PDGFRA and phosphotyrosine were performed. The results indicate that the differences in the sensitivity of PDGFRA mutants to imatinib are a direct consequence of the ability or inability of imatinib to inhibit PDGFRA phosphorylation.

In conclusion, to compare the inhibitory effects of imatinib on PDGFRA $A^{\mathrm{D} 842 \mathrm{~V}}$ and PDGFRA $A^{\mathrm{L} 839 \mathrm{P}}$ with the effects on $P D G F R A^{\mathrm{Wild}}$, with the mutations expressed individually in the same cellular background, we used liposome transduction to transfect these forms of PDGFRA into CHO cells. Our data concerning cell growth, apoptosis and receptor phosphorylation indicate that the $\mathrm{D} 842 \mathrm{~V}$ mutant was resistant to imatinib, which is consistent with the results of previous studies $(22,23)$. Our data also demonstrate that a new mutant, PDGFRA ${ }^{\mathrm{L} 839 \mathrm{P}}$, was more sensitive to imatinib than PDGFRA ${ }^{\text {wild }}$ and $P D G F R A^{\mathrm{D} 842 \mathrm{~V}}$. This study suggests that screening patients for PDGFRA mutations is essential to identify malignancies that are likely to be sensitive or resistant to treatment with imatinib.

\section{Acknowledgements}

This study was supported by the National Natural Science Foundation of China (project numbers 30700809 and 30972876 ).

\section{References}

1. Miettinen M and Lasota J: Gastrointestinal stromal tumors: review on morphology, molecular pathology, prognosis, and differential diagnosis. Arch Pathol Lab Med 130: 1466-1478, 2006.

2. Meng L, Fang SH and Jin M: An unusual case of pancreatic and gastric neoplasms (2010: 12b). Malignant GISTs originating from the pancreas and stomach. Eur Radiol 21: 663-665, 2011.

3. Huizinga JD, Thuneberg L, Klüppel M, Malysz J, Mikkelsen HB and Bernstein A: W/kit gene required for interstitial cells of Cajal and for intestinal pacemaker activity. Nature 373: 347-349, 1995.

4. Sarlomo-Rikala M,Kovatich AJ, Barusevicius A and Miettinen M: CD117: a sensitive marker for gastrointestinal stromal tumors that is more specific than CD34. Mod Pathol 11: 728-734, 1998.

5. Fletcher CD, Berman JJ, Corless C, Gorstein F, Lasota J, Longley BJ, Miettinen M, O'Leary TJ, Remotti H, Rubin BP, et al: Diagnosis of gastrointestinal stromal tumors: A consensus approach. Hum Pathol 33: 459-465, 2002.

6. Hirota S, Isozaki K, Moriyama Y, Hashimoto K, Nishida T, Ishiguro S, Kawano K, Hanada M, Kurata A, Takeda M, et al: Gain-of-function mutations of c-kit in human gastrointestinal stromal tumors. Science 279: 577-580, 1998. 
7. Rubin BP, Singer S, Tsao C, Duensing A, Lux ML, Ruiz R, Hibbard MK, Chen CJ, Xiao S, Tuveson DA, et al: KIT activation is a ubiquitous feature of gastrointestinal stromal tumors. Cancer Res 61: 8118-8121, 2001.

8. Corless CL, Fletcher JA and Heinrich MC: Biology of gastrointestinal stromal tumors. J Clin Oncol 22: 3813-3825, 2004.

9. Hirota S, Ohashi A, Nishida T, Isozaki K, Kinoshita K, Shinomura Y and Kitamura Y: Gain-of-function mutations of platelet-derived growth factor receptor alpha gene in gastrointestinal stromal tumors. Gastroenterology 125: 660-667, 2003.

10. Heinrich MC, Corless CL, Duensing A, McGreevey L, Chen CJ, Joseph N, Singer S, Griffith DJ, Haley A, Town A, et al: PDGFRA activating mutations in gastrointestinal stromal tumors. Science 299: 708-710, 2003.

11. Demetri GD, von Mehren M, Blanke CD, Van den Abbeele AD, Eisenberg B, Roberts PJ, Heinrich MC, Tuveson DA, Singer S, Janicek M, et al: Efficacy and safety of imatinib mesylate in advanced gastrointestinal stromal tumors. N Engl J Med 347: 472-480, 2002

12. van Oosterom AT, Judson I, Verweij J, Stroobants S, Donato di Paola E, Dimitrijevic S, Martens M, Webb A, Sciot R, Van Glabbeke M, Silberman S and Nielsen OS; European Organisation for Research and Treatment of Cancer Soft Tissue and Bone Sarcoma Group: Safety and efficacy of imatinib (STI571) in metastatic gastrointestinal stromal tumours: a phase I study. Lancet 358: 1421-1423, 2001.

13. Tamborini E, Bonadiman L, Greco A, Albertini V, Negri T, Gronchi A, Bertulli R, Colecchia M, Casali PG, Pierotti MA and Pilotti S: A new mutation in the KIT ATP pocket causes acquired resistance to imatinib in a gastrointestinal stromal tumor patient. Gastroenterology 127: 294-299, 2004

14. Buchdunger E, Cioffi CL, Law N, Stover D, Ohno-Jones S, Druker BJ and Lydon NB: Abl protein-tyrosine kinase inhibitor STI571 inhibits in vitro signal transduction mediated by c-kit and platelet-derived growth factor receptors. J Pharmacol Exp Ther 295: 139-145, 2002.

15. Waller CF: Imatinib mesylate. Recent Results Cancer Res 184: 3-20, 2010.

16. Cassier PA and Blay JY: Imatinib mesylate for the treatment of gastrointestinal stromal tumor. Expert Rev Anticancer Ther 10: 623-634, 2010.

17. Lopes LF and Bacchi CE: Imatinib treatment for gastrointestinal stromal tumour (GIST). J Cell Mol Med 14: 42-50, 2010.

18. Marin D: Current status of imatinib as frontline therapy for chronic myeloid leukemia. Semin Hematol 47: 312-318, 2010
19. Mauro MJ and Druker BJ: STI571: targeting BCR-ABL as therapy for CML. Oncologist 6: 233-238, 2001.

20. Casali PG, Messina A, Stacchiotti S, Tamborini E, Crippa F Gronchi A, Orlandi R, Ripamonti C, Spreafico C, Bertieri R, et al: Imatinib mesylate in chordoma. Cancer 101: 2086-2097, 2004.

21. Kérob D, Porcher R, Vérola O, Dalle S, Maubec E, Aubin F, D'Incan M, Bodokh I, Boulinguez S, Madelaine-Chambrin I, et al: Imatinib mesylate as a preoperative therapy in dermatofibrosarcoma: results of a multicenter phase II study on 25 patients. Clin Cancer Res 16: 3288-3295, 2010.

22. Heinrich MC, Corless CL, Demetri GD, Blanke CD, von Mehren M, Joensuu H, McGreevey LS, Chen CJ, Van den Abbeele AD, Druker BJ, et al: Kinase mutations and imatinib response in patients with metastatic gastrointestinal stromal tumor. J Clin Oncol 21: 4342-4349, 2003.

23. Corless CL, Schroeder A, Griffith D, Town A, McGreevey L, Harrell P, Shiraga S, Bainbridge T, Morich J and Heinrich MC: PDGFRA mutations in gastrointestinal stromal tumors: frequency, spectrum and in vitro sensitivity to imatinib. J Clin Oncol 23: 5357-5364, 2005.

24. Yang L, Bai CG, Hou XW, Liu XH and Ma DL: Transforming effect of PDGFRA gene mutant on the cell function in gastrointestinal stromal tumor. Zhonghua Zhong Liu Za Zhi 31: 500-504, 2009 (In Chinese).

25. Lasota J and Miettinen M: Clinical significance of oncogenic KIT and PDGFRA mutations in gastrointestinal stromal tumours. Histopathology 53: 245-266, 2008.

26. Lasota $\mathrm{J}$ and Miettinen M: KIT and PDGFRA mutations in gastrointestinal stromal tumors (GISTs). Semin Diagn Pathol 23: 91-102, 2006.

27. Frost MJ,Ferrao PT, Hughes TP and Ashman LK: Juxtamembrane mutant V560GKit is more sensitive to Imatinib (STI571) compared with wild-type c-kit whereas the kinase domain mutant D816VKit is resistant. Mol Cancer Ther 1: 1115-1124, 2002.

28. Merkelbach-Bruse S, Dietmaier W, Füzesi L, Gaumann A, Haller F, Kitz J, Krohn A, Mechtersheimer G, Penzel R, Schildhaus HU, et al: Pitfalls in mutational testing and reporting of common KIT and PDGFRA mutations in gastrointestinal stromal tumors. BMC Med Genet 11: 106, 2010.

29. Demetri GD, Wang Y, Wehrle E, Racine A, Nikolova Z, Blanke CD, Joensuu $\mathrm{H}$ and von Mehren M: Imatinib plasma levels are correlated with clinical benefit in patients with unresectable/metastatic gastrointestinal stromal tumors. J Clin Oncol 27: 3141-3147, 2009. 